\title{
GENETIC ANALYSIS AND PREDICTION OF NEW RECOMBINATION IN SOME COTTON (G. barbadense L.) CROSSES
}

\author{
A. M. Abd El-Moghny \\ Cotton Breeding Research Section, Cotton Research Institute, \\ Agricultural Research Center, Giza, Egypt
}

\begin{abstract}
Improving cotton breeding programme must depend on the amount of genetic variability between the parental genotypes, which is the main source of genotypic variation among the progeny. The present study was undertaken for the estimation of genetic variability, genetic components and heritability for some yield characters in $F_{2}, F_{3}$ and $F_{4}$ generations derived from two cotton crosses. Estimated Prediction of new recombinant in $F_{3}$ generation and selection was done on $\mathrm{F}_{2}$ to select the most promising plants and the most superior $\mathrm{F}_{3}$ families and plants within each selected family. The results showed some genetic variation among three studied generations, which reflect genetic variability between studied generations. Dominance genetic variance was more important than additive genetic variance in most studied characters. These results indicated that these characters are controlled by non-additive gene type. The analysis of variance for $F_{3}$ generation showed significant differences between $\mathrm{F}_{3}$ families and it's greater than within families in all the studied characters over the two cotton crosses, which show presence of high genetic variability in $F_{3}$ generation. This reflects low values of intra-class variability. So, selection is more effective between families rather than within families. Correlation and regression results between generations showed that $F_{2}$ was not good indicator of $F_{3}$ progeny, while this trend changes from $F_{3}$ to $F_{4}$ generations. Prediction for new recombinant failing outside parental range through $\mathrm{F}_{3}$ generation was higher for all the studied characters. Realized selection differential was higher between and within selected $F_{2}$ plants and $F_{3}$ families. So, the grand mean values of these selected plants and families were higher than grand mean of $F_{2}$ and $F_{3}$ population. Selection between segregating generations coupled with high heritability is a good indicator for selecting promising plants in $F_{2}$ generation and most superior families within $\mathrm{F}_{3}$ families and within each family.
\end{abstract}

Keywords: Cotton (G. barbadense L.), genetic components, intra-class variability, segregating generation, new recombination, realized selection differential.

\section{INTRODUCTION}

Geneticists and cotton breeders are interested to estimate gene effects in order to formulate the most advantageous breeding procedures for improving the quantitative characters. Estimation of additive and dominance components is important for the improvement 
of yield and its components. In order to develop high yielding varieties of cotton, the genetic information of different quantitative and qualitative traits may be helpful cotton breeders to improve genetic architecture of the plant in particular direction for improving and maintaining the proper crop production level. The use of existing genetic variability in the breeding material and the creation of new variability along with its genetic understanding are of crucial importance for this purpose in a breeding program Acquaah, (2007).

Heritability defined as the degree of resemblance between relatives. It is one of the most important genetic parameter on which different breeding strategy depends. The knowledge of heritability is a prerequisite for the formulation of breeding plans on scientific lines as defined by Falconer and Mackey (1996). Thus heritability coupled with genetic advance and genetic variability could be the suitable tool for plant breeder to select the suitable breeding method in order to improve the genetic makeup of cotton plant (Soomro et al. 2010 and Rangantha et al. 2013). The breeding program of any crop mainly depends on the presence of genetic variability present in the breeding materials Aziz et al. (2014).

Crop improvement is based on understanding which genes are involved in a phenotype, as well as the degree of environmental variation. Thus the ability to understand the genetic basis and heritability of characters (phenotype) in breeding programmes provides the opportunity to deploy novel allelic combinations. Abd El-Moghny and Max (2015) studied genotypes $x$ environments interaction and found that environmental variation caused more than $60 \%$ of the total variance on the studied genotypes, while the genotypes variations cause $37.666 \%$ and $35.073 \%$ for seed cotton yield and lint yield characters, respectively.

Selection of superior progenies is a procedure intensive process, once the characters of importance are strongly influenced by the environment and often correlated, so that a selection is one provokes in the other characters (Ramadan et al., 2014 and El-Mansy, 2015 a). Increasing yield is the most important aim in any breeding program. Yield is a complex character with low inheritance and involves several quantitative components, its direct selection is not usually sufficient and therefore it is suggested that its components should be investigated instead. Abd El-Moghny et al. (2015) and El-Mansy (2015 b) found highly significant positive correlation between yield and its components in Egyptian cotton.

The objective of this study is to estimate some descriptive statistics in three segregating generations $F_{2}, F_{3}$ and $F_{4}$ and determine both additive and dominance genetic variances, in order to Predict new recombinant in $\mathrm{F}_{3}$ generation in two cotton crosses. Also, the study will 
be extended to use realized selection differential to select the most promising plants from $F_{2}$ generation in order to select the most superior families in $F_{3}$ generation and the promising plants in each selected family.

\section{MATERIALS AND METHODS}

The plant materials used in this study were the selfed seeds of three segregating generations $F_{2}, F_{3}$ and $F_{4}$ of two intraspecific cotton crosses belonging to Gossypium barbadense $\mathrm{L}$. with their original parents. These breeding materials were obtained from Cotton Breeding programme, Cotton Breeding section, Cotton Research Institute, Agricultural Research Center, Giza, Egypt. The present investigation was carried out at Sakha Experimental Station; Agricultural Research Center, Kafr El-Sheikh; Egypt, during the growing seasons from 2013 to 2015 . The two cotton crosses namely, cross I; (Giza 75 / Sea // Giza 94) and cross II; (Giza 89 / Giza 86 // Giza 94). Origin, pedigree and characterization of these breeding materials are presented in Table 1.

In the growing season of 2013, all the selfed seeds of the $F_{2}$ generation were planted in unreplicated rows to produce $F_{2}$ plants. Each row consisted of 10 single plants spaced $70 \mathrm{~cm}$ apart between plants and rows. At maturity all plants from each cross were harvested to estimate yield characters. Twelve and fifteen superior plants were selected based on yield characters from $F_{2}$ generations to produce $F_{3}$ families seeds.

In the growing season of 2014, the selected plants from $F_{2}$ generation were evaluated as $\mathrm{F}_{3}$ families in a randomized complete block design (RCBD) in two replications with their original parents. Each replicate consisted of two rows for parents and $F_{3}$ families. Each row consisted of 10 single plants spaced $70 \mathrm{~cm}$ apart between plants and rows. At maturity the selected plants from each family were harvested to estimate yield characters in the two crosses. 6 and 8 families from cross I and II, respectively were selected as the superior families then the superior plants from each family were select build the $\mathrm{F}_{4}$ family seeds.

In the growing season of 2015, selfed seeds of selected plants from each selected family were evaluated in a randomized complete block design (RCBD) with two replications. The experimental lay out was the same as carried out in 2014. All other normal culture practices were applied as recommended for ordinary cotton cultivation during the three growing seasons.

At maturity, all the cotton plants were harvested for studying four yield characters, boll weight (BW) seed cotton yield per plant (SCY) 
and lint yield per plant (LY) in grams and lint percentage (L\%) was calculated.

\section{Biometrical assessment}

The original obtained data were statistically analyzed for the four quantitative yield characters. The mean values, standard errors and variances of different generations and their parents were subjected to weight least squares (WLS) technique to estimate simple genetic model [m, $d$ and $h$ ] using the joint scaling test to fit models of increasing complexity until an adequate description of the observed means was found as non-significant $X^{2}$ test according to Mather and Jinks (1982) and Kearsey and Pooni (1996). The used model is:

$$
Y_{i}=c+b_{1} * X_{1 i}+b_{2} * X_{2 i}
$$

Where $Y_{i}, c, b_{1}, b_{2} X_{1 i}$ and $X_{2 i}$ are generation mean, $m,[d]$, [h], the coefficients of [d] and [h], respectively. The biometrical assessment was applied when epitasis was absent and the degree of dominance was also calculated. Heritability in broad sense was estimated correlation ( $r$ ) and linear regression (b) coefficients between the three studied generations were computed according to Falconer (1989) and Falconer and Mackey (1996).

Analysis of variance and genetic components for $F_{3}$ generation

Analysis of variance was carried out to obtain between and within family variances for the studied cotton crosses. The variance values of the $F_{3}$ family mean variance $\left(\bar{V} F_{3}\right)$ (within families), the $F_{3}$ family variance mean $\left(\mathrm{VF}_{3}\right)$ (between families) and homogeneous entries generations mean variance $\left(E_{1}\right)$. Genetic variance components of additive [D] and dominance [H] were estimated as described by Hallauer et al. (1988) and Kearsey and Pooni (1996).

\section{Prediction of new recombinant in $\mathbf{F}_{3}$ generation}

The properties of new recombinant lines derived from a series of selfing generations of a cross between two inbred lines were computed for the $\mathrm{F}_{3}$ generation. The proportion of new recombinant likely to outperform parental $>\mathrm{P}_{1}, \mathrm{P}_{2}$ and those exceeding $\mathrm{F}_{1}$ hybrids, therefore were computed and compared with those observed ones in $\mathrm{F}_{4}$ generation. All these calculation was done as described by Jinks and Pooni (1976). The proportion of recombinant lines corresponding to the probability levels were obtained using Fisher and Yates, (1963) Tables. For this analysis the original data of seed cotton yield, lint yield and lint \% were transformed to root square before statistical analysis as outlined by Folwer and Cohen (1993). 


\section{Selection procedure among studied segregating generations}

The top $5 \%$ superior plants were selected from $\mathrm{F}_{2}$ plants and $\mathrm{F}_{3}$ families on the basis of boll weight, seed cotton yield, lint yield and lint $\%$. Also, realized selection differential ( $r s$ ) was calculated for $F_{2}$ plants and $\mathrm{F}_{3}$ families to detect the superiority of selected plants and families and select the top $5 \%$ superior plants in each selected family as described by Singh and Chaudhary (1979).

Table 1: Origin, pedigree and characterization of the parental cotton genotypes

\begin{tabular}{|l|c|c|c|}
\hline \multicolumn{1}{|c|}{ Genotypes } & Origin & Pedigree & \multicolumn{1}{c|}{ Characterization } \\
\hline Giza 75 / Sea & Egypt & Giza $67 /$ Giza $69 / /$ Sea & $\begin{array}{l}\text { Low boll weight, seed cotton yield and lint } \\
\text { percentage. }\end{array}$ \\
\hline Giza 89 / Giza 86 & Egypt & $\begin{array}{c}\text { Giza } 75 / 6022 / / \text { Giza } 75 / \text { Giza } \\
81\end{array}$ & $\begin{array}{l}\text { Low boll weight, seed cotton yield, lint yield } \\
\text { and lint percentage. }\end{array}$ \\
\hline Giza 94 & Egypt & 10229 / Giza 86 & $\begin{array}{l}\text { High boll weight, seed cotton yield, lint yield } \\
\text { and lint percentage coupled with fiber } \\
\text { length, fiber strength and moderate } \\
\text { micronaire value. }\end{array}$ \\
\hline
\end{tabular}

\section{RESULTS AND DISCUSSION}

The genetic variability of metric characters can be studied through the use of various statistical parameters like mean, median, range and variance components. The mean performance based on the individual data points for yield characters of the three studied generations $F_{2}, F_{3}$ and $F_{4}$ among two crosses are presented in Table 2. Mean and stander error showed significant differences among these generations for all yield characters. Cross I (Giza 75 / Sea // Giza 94) had higher values for most studied yield characters over three generations than cross II (Giza 89 / Giza 86 // Giza 94), this may be related to differences in origin or pedigree. This indicates that these breeding materials had significant differences and mean performance increasing for all yield characters during advanced generations from $\mathrm{F}_{2}$ to $F_{4}$ in the desirable direction; it could be largely attributed to the accumulation of favorable alleles as a result of selection efficiency. Similar results have been reported by Ramadan et al. (2014) and ElMansy (2015 a and b).

The source of genetic variation of $\mathrm{F}_{3}$ generation consists of three portions; non-heritable, two heritable and one co-variance as discussed by Mather and Jinks (1982) and Hallauer et al. (1988). The non-heritable variances are $E_{1}$ is variance component due to plant environmental effects (homogeneous genotypes like parents and $F_{1}$ ). While, the two heritable variance components are the variance of $F_{3}$ 
generation means $\left(\mathrm{VF}_{3}\right)$ (between families), which reflect the genetically differences produced by segregating at gametogenesis in the $\mathrm{F}_{1}$ and mean variances of $\mathrm{F}_{3}$ generation $\left(\bar{V} \mathrm{~F}_{3}\right)$ (within families) reflects the effects of segregation at gametogenesis in the $F_{2}$ individuals. While, the co-variance $\left(\mathrm{WiF}_{23}\right)$ is the covariance between $F_{2}$ generation and $F_{3}$ generation means.

Table 2: Phenotypic mean performance for $F_{2}, F_{3}$ and $F_{4}$ generations for quantitative yield characters of the two studied cotton crosses

\begin{tabular}{|c|c|c|c|c|c|}
\hline Characters & & Mean \pm SE & Minim & Maxim & Median \\
\hline \multicolumn{6}{|c|}{ Giza 75 / Sea // Giza 94} \\
\hline \multirow{3}{*}{ Boll weight (g) } & $\mathbf{F}_{2}$ & $3.540 \pm 0.060$ & 2.900 & 4.117 & 3.570 \\
\hline & $F_{3}$ & $3.593 \pm 0.036$ & 3.160 & 4.850 & 3.460 \\
\hline & $\mathbf{F}_{4}$ & $3.730 \pm 0.034$ & 3.320 & 4.860 & 3.620 \\
\hline \multirow{3}{*}{$\begin{array}{l}\text { Seed cotton yield } \\
(\mathrm{g})\end{array}$} & $F_{2}$ & $269.575 \pm 18.363$ & 97.400 & 443.000 & 268.250 \\
\hline & $\mathrm{F}_{3}$ & $271.687 \pm 7.699$ & 102.200 & 156.200 & 266.650 \\
\hline & $\mathrm{F}_{4}$ & $325.687 \pm 7.699$ & 613.700 & 667.700 & 320.650 \\
\hline \multirow{3}{*}{$\begin{array}{l}\text { Lint yield } \\
\text { (g) }\end{array}$} & $F_{2}$ & $107.264 \pm 7.170$ & 38.100 & 175.074 & 105.000 \\
\hline & $F_{3}$ & $110.568 \pm 3.156$ & 40.100 & 61.553 & 107.874 \\
\hline & $\mathbf{F}_{4}$ & $133.087 \pm 3.182$ & 247.300 & 270.195 & 130.000 \\
\hline \multirow{3}{*}{ Lint \% } & $F_{2}$ & $39.883 \pm 0.192$ & 38.560 & 42.976 & 39.543 \\
\hline & $F_{3}$ & $40.677 \pm 0.136$ & 35.985 & 36.155 & 40.829 \\
\hline & $\mathrm{F}_{4}$ & $40.847 \pm 0.136$ & 44.900 & 45.070 & 40.999 \\
\hline \multicolumn{6}{|c|}{ Giza 89 / Giza 86 // Giza 94} \\
\hline \multirow{3}{*}{ Boll weight (g) } & $F_{2}$ & $3.293 \pm 0.055$ & 2.250 & 3.940 & 3.280 \\
\hline & $F_{3}$ & $3.483 \pm 0.026$ & 2.940 & 3.110 & 3.420 \\
\hline & $\mathrm{F}_{4}$ & $3.753 \pm 0.026$ & 4.340 & 4.510 & 3.590 \\
\hline \multirow{3}{*}{$\begin{array}{c}\text { Seed cotton yield } \\
(\mathrm{g})\end{array}$} & $\mathbf{F}_{2}$ & $267.777 \pm 17.253$ & 123.500 & 498.400 & 267.000 \\
\hline & $F_{3}$ & $311.638 \pm 4.262$ & 203.822 & 266.822 & 307.328 \\
\hline & $F_{4}$ & $374.357 \pm 4.262$ & 453.893 & 516.893 & 370.328 \\
\hline \multirow{3}{*}{$\begin{array}{l}\text { Lint yield } \\
\text { (g) }\end{array}$} & $F_{2}$ & $109.309 \pm 6.597$ & 48.000 & 191.000 & 105.200 \\
\hline & $F_{3}$ & $126.838 \pm 1.749$ & 82.146 & 108.044 & 124.892 \\
\hline & $\mathrm{F}_{4}$ & $152.998 \pm 1.766$ & 191.360 & 218.903 & 150.200 \\
\hline \multirow{3}{*}{ Lint $\%$} & $F_{2}$ & $39.594 \pm 0.253$ & 37.974 & 43.263 & 39.127 \\
\hline & $F_{3}$ & $40.687 \pm 0.104$ & 38.251 & 38.441 & 40.531 \\
\hline & $\mathrm{F}_{4}$ & $40.883 \pm 0.104$ & 44.542 & 44.732 & 40.721 \\
\hline
\end{tabular}

Classification of genetic variation in $\mathrm{F}_{3}$ generation over two crosses is shown in Table 3. The first portion is the non-heritable one, which showed that $E_{1}$ is less because each mean is based on $(m)$ individuals for all the studied characters.

The second portion is the heritable one was described as the component of genetic variation and $\mathrm{F}_{3}$ analysis of variance for quantitative yield characters as shown in Tables $\mathbf{3}$ and $\mathbf{4}$ among two cotton crosses. The estimated variances of $\mathrm{F}_{3}$ generation for the studied characters were high, which suggests the presence of homozygosity among the parental population and variation due to environment is very low, whereas high variance of $F_{3}$ generation for the studied characters is indication for the presence of high genetic variability within the population. While, variance between $F_{3}$ families is greater than within families in all the studied characters over the two crosses (Table 3). So, the $F_{3}$ segregating generation, not only has genetic variability but also had plant to plant variances (intra-class variability) as shown in Table 3 . Therefore, the intra-class variability which is defines as the differences between plants within each family 
as defined by Kearsey and Pooni (1996). Low intra-class variability values were recorded in all the studied characters over two crosses as shown in Table 3, this indicating low variation between plants within each $F_{3}$ families (EI-Mansy, 2005). These results were in harmony with that obtained from the analysis of variance of $F_{3}$ generation means $\left(\mathrm{V}_{1 \mathrm{~F} 3}\right)$ (between families) was significant and highly significant differences for all the studied yield characters over two crosses as shown in Table 4. This showed the presence of high genetic variability among $\mathrm{F}_{3}$ generation and suggested that selection might be more effective between families rather than within families (EI-Mansy, 2005 and Aziz et al., 2014).

Also, genetic components classified to additive and dominance genetic variances. The values of additive genetic variance [D] was smaller than the dominance genetic variance $[\mathrm{H}]$ overall the characters among the two crosses, except boll weight in the first cross (Table 3). These results indicated the relative importance of non fixable or non additive type of gene action in the inheritance of these characters, which may be had higher average degree of dominance. So, the use of intermating population or recurrent selection is better for the improvement of these characters in initial generations. Similar observations in Egyptian cotton were reported by El-Mansy (2005) and Gibely (2015).

The third portion is co-variance between $F_{2}$ and $F_{3}$ generation means $\left(\mathrm{WiF}_{23}\right)$ as shown in Table 3 was ranged from 0.029, 3.053, 1.245 and 0.008 for cross I and $0.047,0.713,0.291$ and 0.001 for cross II for boll weight, seed cotton yield, lint yield and lint \%, respectively. Estimation average degree of dominance of the studied yield characters over the two crosses are shown in Table 3 . The dominance relationships of a pair of alleles or the ratio between $\mathrm{H}$ to $\mathrm{D}$; is the average degree of dominance, which is more than unity and had plus sign for all the studied characters indicating overdominance and parent with increasing alleles is dominant to the parent with decreasing genes. These results in the same trend as obtained by Gibely (2015).

Two methods used to calculate heritability in broad sense $\left(h^{2} b\right)$. The first one defined as the ratio between genotypic to phenotypic variations (Falconer, 1989) is presented in Table 3 ranged from moderately for boll weight, seed cotton yield and lint yield to higher values for lint \% over two crosses, except boll weight in the first cross. This may be due to the higher values of genotypic variance than environmental one, so heritability reflects efficiency of selection producer. Abd El-Moghny et al. (2015) and El-Mansy (2015 b) found higher heritability values for yield characters among $F_{3}$ generation. Gibely et al. (2015) found low value of heritability for boll weight among some Egyptian genotypes. 
The second method to estimate heritability was defied as regression (slope) of offspring on the parents. So, the relationship of mean performance of $F_{3}$ progenies with its $F_{2}$ and between $F_{4}$ progenies with its $F_{3}$ was calculated as the correlation $(r)$ and liner regression (b) coefficients as described by Falconer (1989) and Falconer and Mackey (1996) is given in Table 5. Correlation coefficient $(r)$ was highly significant for all the studied characters over the two crosses between $F_{3}$ and $F_{4}$ only. While, regression coefficients (b) was non significant between $F_{2}$ and $F_{3}$ and highly significant between $F_{3}$ and $F_{4}$ over the two cotton crosses for all yield characters. These results indicated that $F_{2}$ generation was not a good indicator of $\mathrm{F}_{3}$ progeny for such characters but this trend was changed between $F_{3}$ and $\mathrm{F}_{4}$ generations

Table 3: Estimates of variance components for quantitative yield characters of the studied cotton crosses in $\mathrm{F}_{3}$ generation

\begin{tabular}{|c|c|c|c|c|}
\hline Variance components & Boll weight & Seed cotton yield & Lint yield & Lint \% \\
\hline \multicolumn{5}{|c|}{ Giza 75 / Sea // Giza 94} \\
\hline Additive genetic variance [D] & 0.053 & 4.124 & 1.683 & 0.011 \\
\hline Dominance genetic variance $[\mathrm{H}]$ & 0.019 & 7.924 & 3.230 & 0.015 \\
\hline $\begin{array}{l}\text { Variance of } \mathrm{F} 3 \text { generation means }\left(\mathrm{V} \overline{\mathbf{F}}_{3}\right) \text { (between } \\
\text { families) }\end{array}$ & 0.028 & 2.557 & 1.043 & 0.007 \\
\hline Mean variances of $\mathrm{F} 3$ generation $\left(\bar{V} F_{3}\right.$ ) (within families) & 0.016 & 2.022 & 0.825 & 0.005 \\
\hline Homogeneous entries generations mean variance (E1) & 0.157 & 0.487 & 0.203 & 0.058 \\
\hline The co-variance WiF23 & 0.029 & 3.053 & 1.245 & 0.008 \\
\hline Intra-class variability & 0.446 & 0.025 & 0.026 & 0.165 \\
\hline Genotypic variance ( $\left.\sigma^{2} G\right)$ & 0.044 & 1.607 & 0.657 & 0.006 \\
\hline Phenotypic variance $\left(\sigma^{2} \mathrm{Ph}\right)$ & 0.201 & 2.094 & 0.860 & 0.064 \\
\hline Degree of dominance & 1.420 & 1.386 & 1.385 & 1.149 \\
\hline Heritability in broad sense $\left(\mathrm{h}^{2} \mathrm{~b}\right)$ & 0.217 & 0.768 & 0.764 & 0.891 \\
\hline \multicolumn{5}{|c|}{ Giza 89 / Giza 86 // Giza 94} \\
\hline Additive variance [D] & 0.070 & 3.039 & 1.260 & 0.011 \\
\hline Dominance variance $[\mathrm{H}]$ & 0.097 & 5.697 & 2.365 & 0.022 \\
\hline $\begin{array}{l}\text { Variance of } \mathrm{F} 3 \text { generation means }\left(\mathrm{V} \overline{\mathbf{F}}_{3}\right) \text { (between } \\
\text { families) }\end{array}$ & 0.041 & 1.163 & 0.482 & 0.004 \\
\hline Mean variances of $\mathrm{F} 3$ generation $\left(\bar{V} \mathrm{~F}_{3}\right)$ (within families) & 0.030 & 0.048 & 0.019 & 0.000 \\
\hline Homogeneous entries generations mean variance $\left(E_{1}\right)$ & 0.030 & 0.713 & 0.291 & 0.001 \\
\hline The co-variance $\mathrm{WiF}_{23}$ & 0.047 & 0.807 & 0.334 & 0.003 \\
\hline Intra-class variability & 0.419 & 0.073 & 0.039 & 0.010 \\
\hline Genotypic variance $\left(\sigma^{2} G\right)$ & 0.071 & 1.211 & 0.502 & 0.004 \\
\hline Phenotypic variance $\left(\sigma^{2} \mathrm{Ph}\right)$ & 0.101 & 1.924 & 0.792 & 0.005 \\
\hline Degree of dominance & 1.176 & 1.369 & 1.370 & 1.415 \\
\hline Heritability in broad sense $\left(\mathrm{h}^{2} \mathrm{~b}\right)$ & 0.705 & 0.629 & 0.633 & 0.875 \\
\hline
\end{tabular}


Table 4: Analysis of variance for yield characters of $F_{3}$ families in studied cotton crosses

\begin{tabular}{|c|c|c|c|c|c|}
\hline \multicolumn{6}{|c|}{ Mean squares } \\
\hline S.O.v & d.f & Boll weight & $\begin{array}{c}\text { Seed cotton } \\
\text { yield }\end{array}$ & Lint yield & Lint \% \\
\hline \multicolumn{6}{|c|}{ Giza 75 / Sea // Giza 94} \\
\hline Between $F_{3}$ families & 11 & $0.314^{*}$ & $20.535^{\star *}$ & $8.429^{* *}$ & $0.057^{\star *}$ \\
\hline Within $\mathrm{F}_{3}$ families & 108 & 0.140 & 4.867 & 2.033 & 0.009 \\
\hline \multicolumn{6}{|c|}{ Giza 89 / Giza 86 // Giza 94} \\
\hline Between $F_{3}$ families & 14 & $0.710^{*}$ & $18.765^{\star}$ & $7.731^{*}$ & $0.047^{\star *}$ \\
\hline Within $F_{3}$ families & 135 & 0.298 & 7.132 & 2.908 & 0.006 \\
\hline
\end{tabular}

Table 5: Correlation ( $r$ ) and linear regression (b) coefficients between the three generations of the studied cotton crosses

\begin{tabular}{|c|c|c|c|c|c|}
\hline Characters & Generations & $\begin{array}{c}\text { Boll } \\
\text { weight }\end{array}$ & $\begin{array}{c}\text { Seed cotton } \\
\text { yield }\end{array}$ & Lint yield & Lint $\%$ \\
\hline \multicolumn{6}{|c|}{ Giza 75 / Sea // Giza 94} \\
\hline \multirow{2}{*}{ Correlation (r) } & $\mathbf{F}_{2} / \mathbf{F}_{3}$ & 0.069 & 0.247 & 0.228 & 0.170 \\
\hline & $F_{3} / F_{4}$ & $0.978^{* *}$ & $1.000^{* *}$ & $0.998^{* *}$ & $1.000^{* *}$ \\
\hline \multirow{2}{*}{ Regression (b) } & $F_{2} / F_{3}$ & 0.090 & 0.494 & 0.417 & 0.108 \\
\hline & $F_{3} / F_{4}$ & $1.040^{\star *}$ & $1.000^{\star *}$ & $0.992^{* *}$ & $1.000^{* *}$ \\
\hline \multicolumn{6}{|c|}{ Giza 89 / Giza 86 // Giza 94} \\
\hline \multirow{2}{*}{ Correlation ( $r$ ) } & $F_{2} / F_{3}$ & 0.323 & 0.159 & 0.108 & 0.040 \\
\hline & $F_{3} / F_{4}$ & $1.000^{\star *}$ & $1.000^{\star *}$ & $0.776^{\star \star}$ & $0.998^{* *}$ \\
\hline \multirow{2}{*}{ Regression (b) } & $F_{2} / F_{3}$ & 0.320 & 0.336 & 0.210 & 0.045 \\
\hline & $\mathbf{F}_{3} / \mathbf{F}_{4}$ & $0.998^{* *}$ & $0.999^{* *}$ & $1.020^{\star *}$ & $0.995^{\star *}$ \\
\hline
\end{tabular}

* and ** Significant at 0.05 and 0.01 probability levels, respectively.

So, the breeder should focus selection on later generations. These results are in harmony with obtained by El-Mansy (2015 a). Abd El-Salam (2005), El-Mansy (2005 and 2015 a) reported that $F_{2}$ was not a good indicator to $\mathrm{F}_{3}$ progeny. This may be related to; greater genetic variability within $F_{2}$ plants rather than within $F_{3}$ progeny and genotype $x$ environment interaction. Also, dominance gene action in $F_{2}$ population may not be usable in later generations.

\section{generation \\ Predicting the proportion of new recombinant in $F_{3}$}

The three parameters of the simple genetic model [m], additive [d] and dominance [h] gene effects were calculated using weighted least squares (WLS) technique as shown in Tables 6 and 7 . The estimates of mean effects $(m)$, which reflect the contribution due to over-all mean plus the locus effects and interaction of the fixed loci indicted that these characters were quantitatively inherited and dividing 
the genetic components into additive [d] and dominance [h] gene effect over all loci as defined by Hallauer et al. (1988). Abd El-Baky (2006) used weighted least squares (WLS) technique in some segregating generations to detect genetic components among some cotton crosses and found the importance of dominance gene effects for yield character and its components.

The results of predicting the proportion of new recombinants in $\mathrm{F}_{3}$ generation for yield and its components is shown in Table 6 . The proportion of recombinants of inbreed lines that possible outside parental range for the studied characters were 47.608, 32.997, 26.435 and 27.425 for boll weight, seed cotton yield, lint yield and lint \% for cross I (Giza 75 / Sea // Giza 94), respectively. While for cross II (Giza 89 / Giza 86 // Giza 94) it was 12.714, 41.294, 43.644 and 24.510 for the same traits respectively. These results showed that cross II had higher values than cross I. Also, Awaad and Hassan (1996) and ElMansy (2005) reported moderately proportion of new recombinants for yield characters among $\mathrm{F}_{3}$ generation in some cotton crosses failing outside parental range.

However, the promosing recombinant line, $P_{1}$ were 44.433, 10.935 and 22.065 for cross I and $0.344,46.414$ and 43.64 for cross II for boll weight, seed cotton yield and lint yield, respectively while, lint $\%$ character was very low over the two crosses. Also, cross I had higher values than cross II, these results showed that cross II was better than cross I and will be improved rapidly through selection procedures. So, yield and its components can be improved through the Egyptian cotton breeding programme. Awaad and Hassan (1996) reported that the crosses which showed high predictable proportion of inbred outperform parental range and inbred $>P_{1}$ will showed general slight trend when selection was practiced to the highest inbred in the $\mathrm{F}_{4}$ generation and in a few cases for the lowest one $\left(>\mathrm{P}_{2}\right)$.

Predicting the proportion of new recombinant exceeding $F_{1}$ showed higher values for all the studied characters except for lint \% in cross I, but in cross II was low for seed cotton yield and lint yield and very low for lint \% as presented in Table 7 . These results may be related to wider variability between parental genotypes in cross I than cross II. So, cotton breeder should use wider genotypes in hybrization to increase genetic variation in segregating generations and focus selection on these characters to improve it through cotton breeding programme.

The potence ratio is a result value of [h] relative to [d]; showed that all studied characters had the highest values over two crosses except, seed cotton yield and lint yield in cross I and boll weight in cross II as shown in Table 7. These results are indicating dispersion of dominant genes which increase expression between parents and 
ensure transgressive segregation for these characters. Similar conclusion was obtained by El-Mansy (2005). Finally, these results of prediction for new recombinant of $\mathrm{F}_{3}$ generation can help cotton breeder to make great emphasis on these two crosses to improve cotton.

Table 6: Predicting the properties of the new recombination failing outside parental range in the $F_{3}$ generation of the studied cotton crosses

\begin{tabular}{|c|c|c|c|c|c|c|c|c|c|c|}
\hline \multirow[b]{2}{*}{ 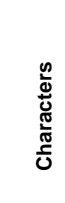 } & \multicolumn{5}{|c|}{ Probability } & \multirow[b]{2}{*}{$\begin{array}{l}\text { Range of } \\
\text { inbreeds } \\
m \pm 2 \sqrt{D}\end{array}$} & \multicolumn{3}{|c|}{ Proportion of inbreeds } & \multirow{2}{*}{ 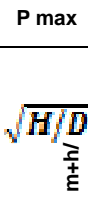 } \\
\hline & [m] & [d] & $\mathrm{d} / \sqrt{D}$ & $\frac{\sqrt{0}}{\frac{m}{!}}$ & $\frac{\sqrt{D}}{\frac{\omega^{m}}{\omega^{2}}}$ & & $\begin{array}{l}\text { Failing } \\
\text { outside } \\
\text { parental } \\
\text { range }\end{array}$ &, $\mathbf{P}_{1}$ & $<\mathbf{P}_{2}$ & \\
\hline \multicolumn{11}{|c|}{ Giza 75 / Sea // Giza 94} \\
\hline BW & 3.089 & 0.382 & 0.064 & -0.148 & 0.020 & $\begin{array}{c}0.259 \pm \\
1.209\end{array}$ & 47.608 & 44.433 & 49.202 & 2.964 \\
\hline SCY & 13.676 & 1.238 & 0.439 & 1.332 & -2.211 & $\begin{array}{c}32.868 \pm \\
44.128\end{array}$ & 32.997 & 10.935 & 1.355 & 17.229 \\
\hline LY & 8.467 & 1.134 & 0.631 & -0.545 & -0.717 & $\begin{array}{c}11.623 \pm \\
18.812\end{array}$ & 26.435 & 29.460 & 22.065 & 11.677 \\
\hline L\% & 6.266 & 0.074 & 0.606 & 22.784 & -23.997 & $\begin{array}{c}0.522 \pm \\
1.012\end{array}$ & 27.425 & - & - & 6.378 \\
\hline \multicolumn{11}{|c|}{ Giza 89 / Giza 86 // Giza 94} \\
\hline BW & 3.113 & 0.358 & 1.147 & -3.989 & -1.695 & $\begin{array}{c}0.347 \pm \\
1.595 \\
\end{array}$ & 12.714 & 0.344 & 4.551 & 2.837 \\
\hline SCY & 14.690 & 0.224 & 0.094 & -1.159 & -0.971 & $\begin{array}{c}30.290 \pm \\
39.837 \\
\end{array}$ & 41.294 & 46.414 & 12.507 & 20.985 \\
\hline LY & 9.354 & 0.248 & 0.161 & 1.155 & -1.478 & $\begin{array}{c}11.309 \pm \\
17.460 \\
\end{array}$ & 43.644 & 43.64 & 73.525 & 12.121 \\
\hline L\% & 6.237 & 0.103 & 0.694 & 12.691 & -14.078 & $\begin{array}{c}0.628 \pm \\
1.222\end{array}$ & 24.510 & - & - & 8.126 \\
\hline
\end{tabular}

Table 7: Predicting the properties of the new recombination exceeding $F_{1}$ in the $F_{3}$ generation of the studied cotton crosses

\begin{tabular}{|c|c|c|c|c|c|}
\hline Characters & [h] & $\begin{array}{l}\text { Potence ratio } \\
{[\mathrm{h}] /[\mathrm{d}]}\end{array}$ & $\begin{array}{l}\text { Probability } \\
{[\mathrm{h}] / \sqrt{\boldsymbol{D}}}\end{array}$ & $\begin{array}{c}\text { Proportion of } \\
\text { inbred } \\
\text { exceeding } F_{1}\end{array}$ & $\begin{array}{l}\text { Actual \% } \\
\text { in } F_{4}\end{array}$ \\
\hline \multicolumn{6}{|c|}{ Giza 75 / Sea // Giza 94} \\
\hline Boll weight & -1.247 & -1.007 & -0.443 & 15.866 & 49.202 \\
\hline Seed cotton yield & -0.039 & -0.034 & -0.022 & 48.803 & 49.202 \\
\hline Lint yield & -0.039 & -0.034 & -0.022 & 48.803 & 49.202 \\
\hline Lint $\%$ & -0.716 & -9.639 & -5.848 & - & - \\
\hline \multicolumn{6}{|c|}{ Giza 89 / Giza 86 // Giza 94} \\
\hline Boll weight & 0.222 & 0.620 & 0.711 & 26.763 & 23.885 \\
\hline Seed cotton yield & 0.636 & 2.840 & 0.266 & 2.255 & 39.743 \\
\hline Lint yield & -0.506 & -2.040 & -0.329 & 2.067 & 1.969 \\
\hline Lint $\%$ & -0.496 & -4.824 & -3.346 & 0.00004 & 0.0041 \\
\hline
\end{tabular}

\section{Selection efficiency in segregating generations}

Cotton breeder used selection parameters as a breeding tool to improve plant productivity, which more adapted with the environment. Also, estimation of genetic variability between and within generation could help cotton breeder to improve new varieties. Estimation of realized selection differential ( $r s$ ) is defined as the differences between 
mean phenotypic value of selected plants and mean phenotypic value of population mean, so breeder can use it as index of selection efficiency in breeding programme (Singh and Chaudhary, 1979).

Selection was done in two levels, the first one between $F_{2}$ plants and $F_{3}$ families to select the most superior plants and families. The second level within each $F_{3}$ family to select the most promising plants in each selected family to be $F_{4}$ families in the next season as shown in Tables 8 and 9 for the two cotton crosses. 12 and 15 plants were selected in $F_{2}$ generation from crosses I and II, respectively, as the most promising plants from $F_{2}$ population to make up $F_{3}$ families in the next season. Most of these plants had higher values more than grand mean of the $F_{2}$ population. Among $F_{3}$ generation 6 and 8 families were selected from cross I and II, respectively which had higher phenotypic mean values than the $F_{3}$ original families mean and has positive values. From these selected families the most promising plants were selected from each selected family for making $\mathrm{F}_{4}$ generation. The last also had higher and positive values realized selection differential (rs). This selection procedure is depending on the higher phenotypic values for seed cotton yield and lint yield for these crosses.

Realized selection differential ( $\mathrm{rs}$ ) between $\mathrm{F}_{2}$ and $\mathrm{F}_{3}$ generations boll weight, seed cotton yield, lint yield and lint \% was $0.041,2.112$, 3.304 and 0.794 , while between $F_{3}$ and $F_{4}$ generations was 0.149 , 54.0, 22.519 and 0.17 for cross I, respectively. On the other hand, for Cross II was 0.122 , 35.55, 17.985 and 1.093 between $F_{2}$ and $F_{3}$, while it was between $\mathrm{F}_{3}$ and $\mathrm{F}_{4} 0.239,61.98,25.862$ and 0.196 , respectively, for boll weight, seed cotton yield, lint yield and lint \%. These results indicated that there was a wide range of genetic variability between these studied generations. Ramadan et al. (2014) and El-Many (2015 a) used direct and indirect selection to select the most promising plants and families during segregating generations.

Realized selection differential ( $r s$ ) within selected $F_{2}$ plants and $F_{3}$ families should be high for the selected plants in $F_{2}$ and $F_{3}$ families as shown in Table 10 for the two crosses. Within $F_{2}$ plants it was 0.153 and $0.019,110.383$ and $96.056,43.399$ and $37.057,-0.165$ and -0.261 for boll weight, seed cotton yield, lint yield and lint \% for cross I and II, respectively. While within $F_{3}$ families were 0.075 and $-0.018,37.874$ and $11.425,15.432$ and $4.102,0.019$ and -0.209 for boll weight, seed cotton yield, lint yield and lint \% for cross I and II, in the same order. Some of the selected plants or families had negative sign for boll and lint \% but most of them had higher and positive sign for seed cotton yield and lint yield over the two studied crosses.

These results showed that there is a high improvement for seed cotton yield and lint yield characters through selection and some reduce in boll weight and lint \%. The study focused on seed cotton 
yield and lint yield characters which showed high variability. So, these results help cotton breeder to select the most superior families. On the other hand, selection must be applied within each selected family to select the most promising plants from the superior family.

Also, the results indicated that these breeding materials have good opportunity for improvement through selection tools. Cotton yield character is a complex character and selection for one reflected character may improve the others (El-Mansy, 2015). On the other hand, Ramadan et al. (2014); Abd El-Moghny et al. (2015) and ElMansy (2015 b) found highly significant positive correlation coefficients between yield character and its components among some Egyptian cotton genotypes. Soomro et al. (2010) reported that selection parameters should be coupled with high heritability estimates to offers effective response to selection.

Table 8: Mean performance of $F_{2}$ plants, $F_{3}$ and $F_{4}$ families for the studied cotton cross I (Giza 75 / Sea // Giza 94)

\begin{tabular}{|c|c|c|c|c|c|}
\hline Generations & No. & Boll weight & $\begin{array}{l}\text { Seed cotton } \\
\text { yield }\end{array}$ & Lint yield & Lint $\%$ \\
\hline \multirow{12}{*}{ Selected $F_{2}$ plants } & 1 & 3.680 & 350.000 & 139.000 & 39.714 \\
\hline & 2 & 4.100 & 326.500 & 130.700 & 40.031 \\
\hline & 3 & 3.900 & 443.000 & 175.074 & 39.520 \\
\hline & 4 & 3.300 & 440.500 & 170.385 & 38.680 \\
\hline & 5 & 3.940 & 319.600 & 128.400 & 40.175 \\
\hline & 6 & 3.760 & 391.000 & 154.700 & 39.565 \\
\hline & 7 & 3.040 & 320.300 & 129.300 & 40.368 \\
\hline & 8 & 3.540 & 442.900 & 175.000 & 39.512 \\
\hline & 9 & 3.960 & 351.200 & 149.000 & 42.426 \\
\hline & 10 & 3.320 & 377.900 & 147.200 & 38.952 \\
\hline & 11 & 4.117 & 430.500 & 166.000 & 38.560 \\
\hline & 12 & 3.660 & 366.100 & 143.200 & 39.115 \\
\hline $\begin{array}{l}\text { Grand mean of } F_{2} \\
\text { plants }\end{array}$ & & $3.54 \pm 0.06$ & $269.57 \pm 18.36$ & $107.26 \pm 7.17$ & $39.88 \pm 0.19$ \\
\hline $\begin{array}{l}\text { Selected mean of } F_{2} \\
\text { plants }\end{array}$ & & $3.69 \pm 0.09$ & $379.95 \pm 14.10$ & $150.66 \pm 5.06$ & $39.71 \pm 0.29$ \\
\hline \multirow{12}{*}{ Selected $F_{3}$ families } & 1 & $3.62 \pm 0.11$ & $240.96 \pm 17.39$ & $101.53 \pm 7.60$ & $42.03 \pm 0.39$ \\
\hline & 2 & $3.62 \pm 0.07$ & $292.01 \pm 15.34$ & $120.51 \pm 6.27$ & $41.28 \pm 0.28$ \\
\hline & 3 & $3.42 \pm 0.01$ & $268.01 \pm 13.31$ & $105.96 \pm 5.75$ & $39.48 \pm 0.51$ \\
\hline & 4 & $3.45 \pm 0.03$ & $206.62 \pm 13.12$ & $81.07 \pm 4.84$ & $39.33 \pm 0.35$ \\
\hline & 5 & $3.57 \pm 0.14$ & $270.88 \pm 21.84$ & $110.04 \pm 8.89$ & $40.57 \pm 0.25$ \\
\hline & 6 & $3.50 \pm 0.13$ & $227.67 \pm 17.41$ & 95.0507 .20 & $41.76 \pm 0.35$ \\
\hline & 7 & $3.60 \pm 0.15$ & $320.07 \pm 34.55$ & $133.89 \pm 14.67$ & $41.67 \pm 0.60$ \\
\hline & 8 & $3.44 \pm 0.14$ & $188.74 \pm 23.62$ & $77.15 \pm 9.81$ & $40.76 \pm 0.26$ \\
\hline & 9 & $3.57 \pm 0.11$ & $297.69 \pm 20.25$ & $123.71 \pm 9.31$ & $41.38 \pm 0.49$ \\
\hline & 10 & $3.47 \pm 0.03$ & $295.96 \pm 19.46$ & $122.66 \pm 7.10$ & $41.44 \pm 0.31$ \\
\hline & 11 & $3.56 \pm 0.10$ & $319.46 \pm 32.87$ & $128.63 \pm 13.30$ & $40.26 \pm 0.33$ \\
\hline & 12 & $4.09 \pm 0.2$ & $332.17 \pm 38.12$ & $132.86 \pm 15.00$ & $40.11 \pm 0.35$ \\
\hline $\begin{array}{l}\text { Grand mean of } F_{3} \\
\text { families }\end{array}$ & & $3.58 \pm 0.06$ & $271.68 \pm 7.69$ & $110.56 \pm 3.15$ & $40.67 \pm 0.13$ \\
\hline \multirow[t]{7}{*}{$\begin{array}{l}\text { Mean of selected } F_{3} \\
\text { families }\end{array}$} & & $3.65 \pm 0.00$ & $309.56 \pm 6.71$ & $126.00 \pm 2.85$ & $40.69 \pm 0.35$ \\
\hline & 2 & $3.78 \pm 0.079$ & $346.01 \pm 15.34$ & $143.40 \pm 6.31$ & $41.45 \pm 0.28$ \\
\hline & 7 & $3.58 \pm 0.01$ & $322.010 \pm 13.31$ & $127.83 \pm 5.90$ & $39.65 \pm 0.51$ \\
\hline & 9 & $3.68 \pm 0.09$ & $324.880 \pm 21.84$ & $132.50 \pm 8.97$ & $40.74 \pm 0.25$ \\
\hline & 10 & $3.76 \pm 0.15$ & $374.070 \pm 34.55$ & $157.03 \pm 14.86$ & $41.84 \pm 0.60$ \\
\hline & 11 & $3.73 \pm 0.11$ & $351.690 \pm 20.25$ & $146.65 \pm 9.53$ & $41.55 \pm 0.49$ \\
\hline & 12 & $4.17 \pm 0.19$ & $386.176 \pm 38.12$ & $155.18 \pm 15.01$ & $40.28 \pm 0.35$ \\
\hline $\begin{array}{l}\text { Grand mean of } F_{4} \\
\text { families }\end{array}$ & & $3.73 \pm 0.03$ & $350.839 \pm 7.69$ & $143.76 \pm 3.18$ & $40.92 \pm 0.13$ \\
\hline
\end{tabular}


In conclusion, this study is to estimate the increase of yield characters during advanced generations, which indicating accumulation of favorable alleles as a result of selection efficiency. Non additive gene action controlling yield characters and variation among $F_{3}$ families were highly significant and greater than within family's low values of intra-class variability. Yield and its components is a complex character and indirect selection should be used for improve these characters. The cotton breeder should use selection differential coupled with high heritability aiming to improve cotton breeding programme.

Table 9: Mean performance of $F_{2}$ plants, $F_{3}$ and $F_{4}$ families for the studied cotton cross II (Giza 89 / Giza 86 // Giza 94)

\begin{tabular}{|c|c|c|c|c|c|}
\hline Generations & No. & Boll weight & $\begin{array}{l}\text { Seed cotton } \\
\text { yield }\end{array}$ & Lint yield & Lint $\%$ \\
\hline \multirow{15}{*}{ Selected $F_{2}$ plants } & 1 & 2.520 & 300.400 & 119.500 & 39.780 \\
\hline & 2 & 3.300 & 445.300 & 169.100 & 37.974 \\
\hline & 3 & 3.240 & 289.900 & 110.900 & 38.255 \\
\hline & 4 & 3.400 & 313.000 & 123.100 & 39.329 \\
\hline & 5 & 2.840 & 384.000 & 146.900 & 38.255 \\
\hline & 6 & 3.080 & 447.800 & 172.500 & 38.522 \\
\hline & 7 & 3.320 & 308.800 & 131.394 & 42.550 \\
\hline & 8 & 3.440 & 408.200 & 159.000 & 38.951 \\
\hline & 9 & 3.480 & 417.400 & 160.000 & 38.333 \\
\hline & 10 & 3.160 & 498.400 & 191.000 & 38.323 \\
\hline & 11 & 3.620 & 358.500 & 154.600 & 43.124 \\
\hline & 12 & 3.700 & 297.900 & 118.800 & 39.879 \\
\hline & 13 & 3.940 & 360.200 & 142.000 & 39.423 \\
\hline & 14 & 3.140 & 415.600 & 159.600 & 38.402 \\
\hline & 15 & 3.500 & 347.100 & 135.000 & 38.894 \\
\hline Grand mean of $F_{2}$ plants & & $3.29 \pm 0.05$ & $276.77 \pm 17.25$ & $109.15 \pm 6.59$ & $39.59 \pm 0.25$ \\
\hline Mean of selected $F_{2}$ plants & & $3.31 \pm 0.09$ & $372.83 \pm 16.65$ & $146.22 \pm 5.95$ & $39.33 \pm 0.39$ \\
\hline \multirow{15}{*}{ Selected $F_{3}$ families } & 1 & $3.40 \pm 0.06$ & $282.39 \pm 16.65$ & $112.25 \pm 7.12$ & $39.67 \pm 0.27$ \\
\hline & 2 & $3.50 \pm 0.14$ & $273.91 \pm 12.33$ & $108.76 \pm 5.11$ & $39.68 \pm 0.28$ \\
\hline & 3 & $3.48 \pm 0.12$ & $295.09 \pm 18.47$ & $123.02 \pm 7.18$ & $41.79 \pm 0.35$ \\
\hline & 4 & $3.36 \pm 0.07$ & $310.01 \pm 14.96$ & $124.72 \pm 6.06$ & $41.23 \pm 0.33$ \\
\hline & 5 & $3.38 \pm 0.09$ & $317.12 \pm 16.00$ & $126.90 \pm 6.23$ & $40.05 \pm 0.21$ \\
\hline & 6 & $3.41 \pm 0.06$ & $285.99 \pm 11.74$ & $122.35 \pm 4.35$ & $42.87 \pm 0.35$ \\
\hline & 7 & $3.47 \pm 0.09$ & $309.86 \pm 24.01$ & $127.20 \pm 9.47$ & $41.12 \pm 0.27$ \\
\hline & 8 & $3.47 \pm 0.11$ & $312.25 \pm 15.94$ & $128.87 \pm 6.66$ & $41.27 \pm 0.25$ \\
\hline & 9 & $3.41 \pm 0.10$ & $323.08 \pm 18.56$ & $129.70 \pm 7.61$ & $40.11 \pm 0.19$ \\
\hline & 10 & $3.38 \pm 0.07$ & $315.21 \pm 13.73$ & $125.50 \pm 4.75$ & $39.90 \pm 0.35$ \\
\hline & 11 & $3.59 \pm 0.08$ & $324.26 \pm 17.26$ & $130.48 \pm 7.59$ & $40.15 \pm 0.30$ \\
\hline & 12 & $3.32 \pm 0.06$ & $346.55 \pm 18.64$ & $142.21 \pm 7.62$ & $41.06 \pm 0.32$ \\
\hline & 13 & $3.61 \pm 0.12$ & $321.12 \pm 13.33$ & $129.74 \pm 6.34$ & $40.30 \pm 0.35$ \\
\hline & 14 & $3.82 \pm 0.12$ & $324.40 \pm 11.01$ & $132.18 \pm 5.07$ & $40.71 \pm 0.46$ \\
\hline & 15 & $2.56 \pm 0.56$ & $339.32 \pm 51.48$ & $138.03 \pm 20.92$ & $40.35 \pm 0.28$ \\
\hline Grand mean of $F_{3}$ plants & & $3.41 \pm 0.02$ & $312.37 \pm 4.26$ & $127.13 \pm 1.74$ & $40.68 \pm 0.10$ \\
\hline Mean of selected $F_{3}$ families & & $3.39 \pm 0.13$ & $323.80 \pm 3.80$ & $131.23 \pm 1.85$ & $40.47 \pm 0.17$ \\
\hline \multirow{8}{*}{ Selected $\mathrm{F}_{4}$ families } & 5 & $3.57 \pm 0.06$ & $345.39 \pm 16.65$ & $137.90 \pm 7.27$ & $39.86 \pm 0.27$ \\
\hline & 8 & $3.53 \pm 0.07$ & $378.01 \pm 14.96$ & $156.47 \pm 6.07$ & $41.42 \pm 0.33$ \\
\hline & 9 & $3.55 \pm 0.08$ & $380.12 \pm 16.00$ & $152.85 \pm 6.22$ & $40.24 \pm 0.20$ \\
\hline & 10 & $3.58 \pm 0.05$ & $348.99 \pm 11.74$ & $150.02 \pm 4.24$ & $43.06 \pm 0.35$ \\
\hline & 11 & $3.58 \pm 0.10$ & $386.08 \pm 18.56$ & $155.71 \pm 7.69$ & $40.30 \pm 0.18$ \\
\hline & 12 & $3.76 \pm 0.08$ & $387.26 \pm 17.26$ & $156.51 \pm 7.75$ & $40.34 \pm 0.29$ \\
\hline & 13 & $3.49 \pm 0.06$ & $409.55 \pm 18.64$ & $168.86 \pm 7.66$ & $41.25 \pm 0.32$ \\
\hline & 14 & $3.99 \pm 0.12$ & $387.40 \pm 11.01$ & $158.57 \pm 5.25$ & $40.90 \pm 0.46$ \\
\hline Grand mean of $F_{4}$ families & & $3.63 \pm 0.02$ & $377.85 \pm 4.26$ & $154.61 \pm 1.76$ & $40.92 \pm 0.10$ \\
\hline
\end{tabular}


Table 10: Realized selection differential ( $r s$ ) within $F_{2}$ plants and $\mathrm{F}_{3}$ families for the studied cotton crosses

\begin{tabular}{|c|c|c|c|c|c|}
\hline Characters & No. & $\begin{array}{c}\text { Boll } \\
\text { weight }\end{array}$ & $\begin{array}{c}\text { Seed cotton } \\
\text { yield }\end{array}$ & Lint yield & Lint \% \\
\hline \multicolumn{6}{|c|}{ Giza 75 / Sea // Giza 94} \\
\hline \multirow{12}{*}{\begin{tabular}{llr} 
Realized & \multicolumn{2}{c}{ selection } \\
differential & (rs) for \\
selected $F_{2}$ plants
\end{tabular}} & 1 & 0.140 & 80.425 & 31.736 & -0.169 \\
\hline & 2 & 0.560 & 56.925 & 23.436 & 0.148 \\
\hline & 3 & 0.360 & 173.425 & 67.810 & -0.363 \\
\hline & 4 & -0.240 & 170.925 & 63.121 & -1.203 \\
\hline & 5 & 0.400 & 50.025 & 21.136 & 0.292 \\
\hline & 6 & 0.220 & 121.425 & 47.436 & -0.318 \\
\hline & 7 & -0.500 & 50.725 & 22.036 & 0.485 \\
\hline & 8 & 0.000 & 173.325 & 67.736 & -0.371 \\
\hline & 9 & 0.420 & 81.625 & 41.736 & 2.543 \\
\hline & 10 & -0.220 & 108.325 & 39.936 & -0.931 \\
\hline & 11 & 0.577 & 160.925 & 58.736 & -1.323 \\
\hline & 12 & 0.120 & 96.525 & 35.936 & -0.768 \\
\hline \multirow{12}{*}{$\begin{array}{l}\text { Realized selection } \\
\text { differential (rs) for } \\
\text { selected } F_{3} \text { families }\end{array}$} & 1 & 0.046 & -30.727 & -9.034 & 1.357 \\
\hline & 2 & 0.043 & 20.323 & 9.952 & 0.608 \\
\hline & 3 & -0.153 & -3.677 & -4.608 & -1.192 \\
\hline & 4 & -0.127 & -65.067 & -29.490 & -1.346 \\
\hline & 5 & -0.006 & -0.807 & -0.528 & -0.100 \\
\hline & 6 & -0.074 & -44.017 & -15.518 & 1.089 \\
\hline & 7 & 0.021 & 48.383 & 23.322 & 1.000 \\
\hline & 8 & -0.139 & -82.947 & -33.418 & 0.082 \\
\hline & 9 & -0.010 & 26.003 & 13.147 & 0.703 \\
\hline & 10 & -0.103 & 24.273 & 5.817 & -1.232 \\
\hline & 11 & -0.016 & 47.773 & 18.062 & -0.410 \\
\hline & 12 & 0.516 & 60.489 & 22.293 & -0.559 \\
\hline \multicolumn{6}{|c|}{ Giza 89 / Giza 86 // Giza 94} \\
\hline \multirow{15}{*}{$\begin{array}{l}\text { Realized selection } \\
\text { differential (rs) for } \\
\text { selected } F_{2} \text { plants }\end{array}$} & 1 & -0.773 & 23.623 & 10.349 & 0.186 \\
\hline & 2 & 0.007 & 168.523 & 59.949 & -1.620 \\
\hline & 3 & -0.053 & 13.123 & 1.749 & -1.339 \\
\hline & 4 & 0.107 & 36.223 & 13.949 & -0.265 \\
\hline & 5 & -0.453 & 107.223 & 37.749 & -1.339 \\
\hline & 6 & -0.213 & 171.023 & 63.349 & -1.072 \\
\hline & 7 & 0.027 & 32.023 & 22.243 & 2.956 \\
\hline & 8 & 0.147 & 131.423 & 49.849 & -0.643 \\
\hline & 9 & 0.187 & 140.623 & 50.849 & -1.261 \\
\hline & 10 & -0.133 & 221.623 & 81.849 & -1.271 \\
\hline & 11 & 0.327 & 81.723 & 45.449 & 3.530 \\
\hline & 12 & 0.407 & 21.123 & 9.649 & 0.285 \\
\hline & 13 & -0.773 & 23.623 & 10.349 & 0.186 \\
\hline & 14 & 0.007 & 168.523 & 59.949 & -1.620 \\
\hline & 15 & -0.053 & 13.123 & 1.749 & -1.339 \\
\hline \multirow{15}{*}{\begin{tabular}{lll} 
Realized & \multicolumn{2}{c}{ selection } \\
differential $\quad$ (rs) for \\
selected $F_{3}$ families
\end{tabular}} & 1 & -3.586 & -28.962 & -15.090 & -1.023 \\
\hline & 2 & -3.519 & -37.441 & -18.595 & -1.013 \\
\hline & 3 & -3.535 & -16.258 & -2.966 & 1.098 \\
\hline & 4 & -3.585 & 3.659 & 3.472 & 0.538 \\
\hline & 5 & -3.568 & 5.771 & -0.139 & -0.643 \\
\hline & 6 & -3.598 & -25.363 & -2.974 & 2.183 \\
\hline & 7 & -3.564 & -1.489 & 0.820 & 0.429 \\
\hline & 8 & -3.549 & 0.896 & 2.596 & 0.582 \\
\hline & 9 & -3.552 & 11.724 & 2.716 & -0.579 \\
\hline & 10 & -3.579 & 3.862 & -1.629 & -0.785 \\
\hline & 11 & -3.573 & 12.910 & 3.518 & -0.536 \\
\hline & 12 & -3.593 & 35.200 & 15.869 & 0.370 \\
\hline & 13 & -3.532 & 9.769 & 2.869 & -0.388 \\
\hline & 14 & -3.535 & 13.047 & 5.573 & 0.019 \\
\hline & 15 & -3.550 & 12.674 & 3.962 & -0.251 \\
\hline
\end{tabular}

REFERENCES

Abd El-Baky, A. M. A. (2006). Genetic consequences of incorporating foreign genes into some Egyptian cottons. M. Sc Thesis, Fac., Agric., Zagazig Univ., Egypt.

Abd El-Moghny, A. M. and Mariz, S. Max (2015). Genotypic stability and phenotypic adaptability for some yield traits in some long staple cotton genotypes. Egypt. J. Agric. Res., 93 (1), 85-100. 
Abd El-Moghny, A. M., Reham, H. A. O. Gibely and Mariz, S. Max (2015). Genetic variation and associations between some agronomic, chemical seed components and seedling vigor characters in some cotton varieties. Bull. Fac. Agric. Cairo Univ. 66: (4): 390-399.

Abd El-Salam, M. E. (2005). Studies on breeding and maintenance of cotton varieties G. barbadense L. Ph. D. thesis, Fac. Agric., Kafr El-Sheikh, Tanta Univ., Egypt.

Acquaah, G. (2007). Principles of Plant Genetics and Breeding. Blackwell Publishing, USA.

Awaad, H. A. and E. E. Hassan (1996). Gene action, prediction and response to selection for yield and its contributing characters in six cotton crosses. Zagazig, J. Agric. Res., 23(2): 217-237.

Aziz, U. J. Afzal, M. Iqbal, M. Naeem, M. A. Khan, W. Nazeer, T. Aslam and W. Zahid (2014). Selection response, heritability and genetic variability studies in upland cotton. J. Appl. Environ. Biol. Sci., 4(8S):400-412.

El-Mansy, Y. M. (2005). Using genetic components for predicting new combination in some cotton cresses (Gossypium barbadense L.,). Ph. D. Thesis, Fac., Agric., Mansoura Univ., Egypt.

El-Mansy, Y. M. (2015 a). Relative efficiency of direct and indirect selection with selection indices for improving some economic characters in cotton (G. barbadense L.). J. Agric. Res. Kafr ElSheikh Univ., 41(1):192-215.

El-Mansy, Y. M. (2015 b). Impact of mating system on genetic variability and correlation coefficients in cotton (G. barbadense L.,). Minufiya J. Agic. Res. 40(1): 119-129.

Falconer, D. S. (1989). Introduction of Quantitative Genetics. $3^{\text {rd }}$ ed. Longman, England.

Falconer, D. S. and T. F. C. Mackey (1996). Introduction of Quantitative Genetics. $4^{\text {th }}$ ed. Longman, England.

Fisher, R. A. and F. Yates (1963). Statistical Tables for Biological Agricultural and Medical Research. Edinburgh. Oliver and Boyd.

Folwer, J. and L. Cohen (1993). Practical Statistics for Field Biology. John Wiley \& Sons Ltd, England.

Gibely, H. A. Reham (2015). Genetic analysis of some yield and fiber quality traits in cotton. Egypt. J. Plant Breed. 19(4):1061-1074.

Gibely, H. A. Reham; Aziza M. Soultan, H. A. El-Hoseiny and E. A. Amer (2015). Assessment of genetic variability and stability for some cotton genotypes. Egypt. J. Plant Breed. 19(6):1783 - 1801.

Hallauer, A. R.; M. J. Carena and J. B. F. Miranda (1988). Quantitative Genetics in Maize Breeding. $4^{\text {th }}$ edition. Iowa State University Press, Ames, lowa, U.S.A.

Jinks, I. L. and H. S. Pooni (1976). Predicting the properties of recombinant inbred lines derived by single seed descent. Heredity 36: 253-266.

Kearsey, M. J. and H. S. Pooni (1996). The Genetical Analysis of Quantitative Traits. Chapman \& Hall, London, UK. 
Mather, K. and T. L. Jinks (1982). Biometrical Genetics. $3^{\text {th }}$ edition, Chapman \& Hall, London.

Ramadan, B. M.; Y. M. El-Mansy; M. A. Al-Ameer and M. A. Abou ElYazied (2014). Improvement of some economic characters through direct and indicated selection in Egyptian cotton. Egypt. J. Plant Breed. 18(4):783-797.

Rangantha, H. M., S. S. Patil, S. M. Manjula and B. N. Arvindkumar (2013). Genetic variability studies in segregating generation of Upland cotton (Gossypium hirsutum L.). Molecular plant breeding, 4(10): 84-88.

Singh R. K. and B. D. Chaudhary (1979). Biometrical Methods in Quantitative Genetic Analysis. Kalyani Publishers, New Delhi, India.

Soomro, Z. A., M. B. Kumbhar, A. S. Larik, M. Imran and S. A. Brohi (2010). Heritability and selection response in segregating generation of Upland cotton. Pakistan J. Agric. Res. 23 (1-2): 2530.

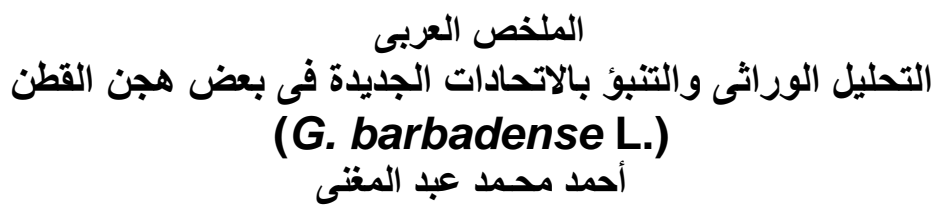

قسم بحوث تربية القطن ، معهل بحوث القطن ، مركز البحوث الزراعية ، الجيزة ، مصر

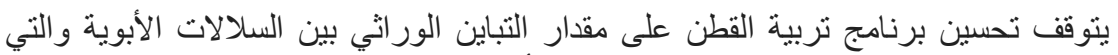

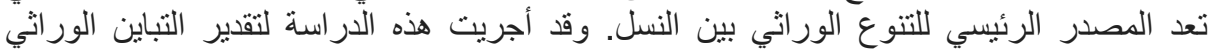

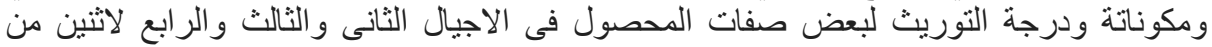

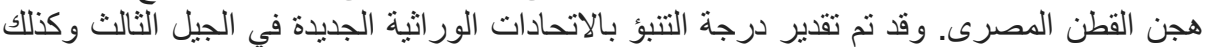

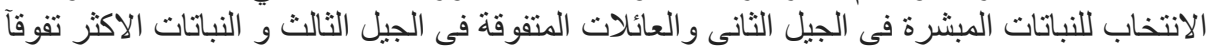

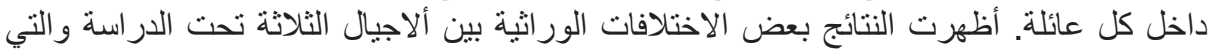

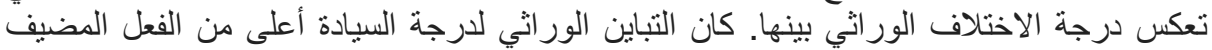

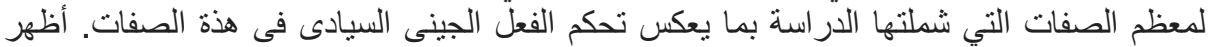

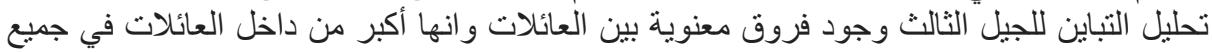

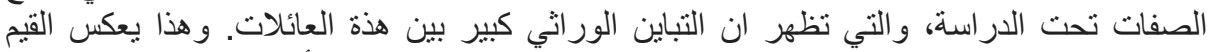

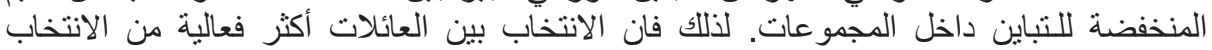

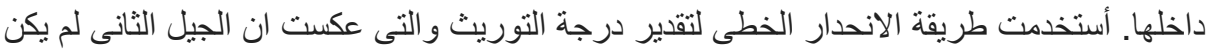

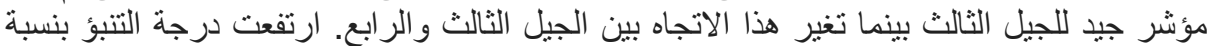

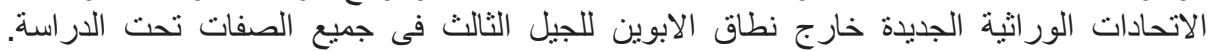

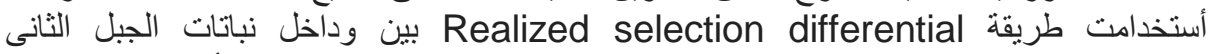

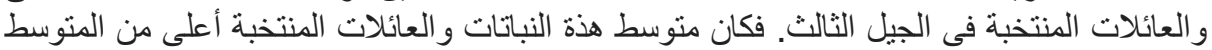

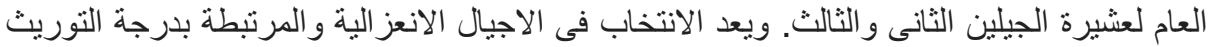

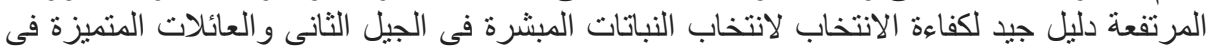
الجيل الثالث و النباتات الأكثر تميز داخل كل التخ عائلة منتخبة. 